\section{Container Size and Shade Duration Affect Growth of Flowering Dogwood}

\author{
Anthony L. Witcher ${ }^{1}$, Fulya Baysal-Gurel ${ }^{1}$, Eugene K. Blythe ${ }^{2}$, \\ and Donna C. Fare ${ }^{3}$
}

AdDitional INDEX wORDs. container production, Cornus florida, native tree, nursery production, powdery mildew

SumMARY. Flowering dogwood (Cornus flovida) is a valuable nursery product typically produced as a field-grown crop. Container-grown flowering dogwood can grow much faster than field-grown plants, thus shortening the production cycle, yet unacceptable crop loss and reduced quality continue to be major issues with container-grown plants. The objective of this research was to evaluate the effects of container size and shade duration on growth of flowering dogwood cultivars Cherokee Brave ${ }^{\mathrm{TM}}$ and Cherokee Princess from bare-root liners. In 2015, bare-root liners were transplanted to 23-L (no. 7) containers and placed under shade for 0 months (full sun), 2 months (sun4/shade2), 4 months (sun2/shade4), or 6 months (full shade) during the growing season. In 2016, one-half of the plants remained in no. 7 containers and the other half were transplanted to 50-L (no. 15) containers and assigned to the same four shade treatments. In 2015, plant height was greatest with full shade for both cultivars, whereas stem diameter and shoot dry weight (SDW) were greatest in full shade for Cherokee Brave ${ }^{\mathrm{TM}}$. In 2016, both cultivars in no. 15 containers had greater plant height, stem diameter, root dry weight (RDW), and SDW. Full shade resulted in the greatest height, stem diameter, RDW, and SDW for Cherokee Brave ${ }^{\mathrm{TM}}$, and improved overall growth for ' Cherokee Princess'. However, vigorous growth due to container size and shade exposure increased the severity of powdery mildew (Erysiphe pulchra) in both years. Substrate leachate nutrient concentration (nitrate nitrogen and phosphate) was greater in no. 15 containers but shade duration had no effect.

$\mathrm{F}$ lowering dogwood is native to the eastern United States from Texas to Massachusetts (Witte et al., 2000). Flowering dogwood continues to be a valuable crop for nursery producers. It is ranked third in total sales value among flowering trees, behind only crape myrtle (Lagerstroemia indica) and flowering cherry (Prunus serrulata), and it accounts for more than $7.5 \%$ of the total value of all flowering trees sold in the

Received for publication 29 Apr. 2019. Accepted for publication 8 Aug. 2019

Published online 2 October 2019

${ }^{1}$ Tennessee State University, Otis L. Floyd Nursery Research Center, McMinnville, TN 37110

${ }^{2}$ Coastal Research and Extension Center, Mississippi State University, South Mississippi Branch Experiment Station, Poplarville, MS 39470

${ }^{3}$ U.S. Department of Agriculture, Agricultural Research Service, U.S. National Arboretum, Otis L. Floyd Nursery Research Center, 472 Cadillac Lane, McMinnville, TN 37110

This project was supported in part by the USDANIFA Hatch Project MIS-219060.

A.L.W. is the corresponding author. E-mail: awitcher@tnstate.edu.

This is an open access article distributed under the CC BY-NC-ND license (https://creativecommons.org/ licenses/by-nc-nd/4.0/).

https://doi.org/10.21273/HORTTECH04392-19
United States (U.S. Department of Agriculture, 2019). Although flowering dogwood can be grown throughout a wide geographical region, three states (Tennessee, Florida, and Oregon) produce more than $75 \%$ of the plants within the nursery industry (U.S. Department of Agriculture, 2019 ). Field production is the most common method used for commercially grown flowering dogwood in Tennessee (Halcomb, 2002). Plants can be harvested as either bare-root or balled and burlap $(B \& B)$, depending on the plant size and intended use.
Although field production is the least expensive method of growing flowering dogwood, the long production cycle and limited transplant window for $B \& B$ nursery stock have led to increased interest in growing flowering dogwood in containers. Additionally, the market for container-grown flowering dogwood has expanded due to year-round sales of plants and demand from garden centers and large retailers.

Container-grown flowering dogwood can be a challenging crop due to a number of factors. Container-grown liners of flowering dogwood seedlings and cultivars are not widely available; therefore, most growers must transplant bare-root liners into containers. Bare-root liners have fewer roots and less root biomass compared with containerized liners due to harvesting, which can delay shoot growth and development. Burrows et al. (2015) reported that improper irrigation management, excessive fertilization, poor root development, and delayed budbreak can hinder development of bare-root liners during container production. In addition to problems soon after transplantation, flowering dogwood plants are sensitive to overwatering and highly soluble salts during production. Recommended practices include the use of cyclic irrigation, low to medium rates of controlled-release fertilizer, and frequent monitoring of water needs and soluble salt levels in the substrate (Fulcher and White, 2012). Powdery mildew is also a major issue during flowering dogwood production. Powdery mildew may cause cosmetic damage, including redbrown patches, reduced growth, and premature defoliation. A routine fungicide spray schedule is recommended between May and October in

\begin{tabular}{llll}
\hline $\begin{array}{l}\text { Units } \\
\text { To convert U.S. to SI, } \\
\text { multiply by }\end{array}$ & U.S. unit & Sl unit & $\begin{array}{l}\text { To convert SI to U.S., } \\
\text { multiply by }\end{array}$ \\
\hline 29.5735 & $\mathrm{fl} \mathrm{oz}$ & $\mathrm{mL}$ & 0.0338 \\
0.3048 & $\mathrm{ft}$ & $\mathrm{m}$ & 3.2808 \\
3.7854 & gal & $\mathrm{L}$ & 0.2642 \\
2.54 & inch $(\mathrm{es})$ & $\mathrm{cm}$ & 0.3937 \\
25.4 & inch $(\mathrm{es})$ & $\mathrm{mm}$ & 0.0394 \\
1.1983 & $\mathrm{lb} / 100 \mathrm{gal}$ & $\mathrm{g} \cdot \mathrm{L}^{-1}$ & 0.8345 \\
48.8243 & $\mathrm{lb} / 1000 \mathrm{ft}^{2}$ & $\mathrm{~kg} \cdot \mathrm{ha}^{-1}$ & 0.0205 \\
1.1209 & $\mathrm{lb} / \mathrm{acre}$ & $\mathrm{kg} \cdot \mathrm{ha}^{-1}$ & 0.8922 \\
0.5933 & $\mathrm{lb} / \mathrm{yard} \mathrm{d}^{3}$ & $\mathrm{~kg} \cdot \mathrm{m}^{-3}$ & 1.6856 \\
28.3495 & $\mathrm{oz}$ & $\mathrm{g}$ & 0.0353 \\
1 & $\mathrm{ppm}$ & $\mathrm{mg} \cdot \mathrm{L}^{-1}$ & 1 \\
6.8948 & $\mathrm{psi}$ & $\mathrm{kPa}$ & 0.1450 \\
$\left({ }^{\circ} \mathrm{F}-32\right) \div 1.8$ & ${ }^{\circ} \mathrm{F}$ & ${ }^{\circ} \mathrm{C}$ & $\left({ }^{\circ} \mathrm{C} \times 1.8\right)+32$
\end{tabular}


Table 1. Plant height, stem diameter, and height:diameter ratio on three dates in $2015(n=40)$ and root dry weight, shoot dry weight, and root:shoot dry weight ratio upon harvest on 5 Nov. $2015(\mathrm{n}=12)$ of Cherokee Brave ${ }^{\mathrm{TM}}$ and 'Cherokee Princess' flowering dogwood planted as bare-root plants in no. 7 [ $23 \mathrm{~L}(6.1 \mathrm{gal})$ ] containers in a pine bark substrate on 12 Mar. 2015 and grown using four different shade treatments in McMinnville, TN.

\begin{tabular}{|c|c|c|c|c|c|c|c|c|c|c|c|c|}
\hline \multirow[b]{3}{*}{ Treatment $^{\mathrm{z}}$} & \multicolumn{3}{|c|}{ Plant ht $(\mathrm{cm})^{\mathrm{y}}$} & \multicolumn{3}{|c|}{ Stem diam $(\mathrm{mm})^{\mathrm{x}}$} & \multicolumn{3}{|c|}{$\begin{array}{c}\text { Plant ht:stem diam } \\
\text { (ratio) }\end{array}$} & \multicolumn{3}{|c|}{$\operatorname{Dry} w t(g)^{y}$} \\
\hline & July & Aug. & Nov. & July & Aug. & Nov. & July & Aug. & Nov. & Root & Shoot & Root:shoot (ratio) \\
\hline & \multicolumn{12}{|c|}{ Cherokee Brave $^{\mathrm{TM}}$} \\
\hline Full sun & $80.8 b^{w}$ & $86.0 \mathrm{~b}$ & $94.2 \mathrm{c}$ & $11.7 \mathrm{~d}$ & $14.0 \mathrm{~b}$ & $17.2 \mathrm{~b}$ & $69.6 \mathrm{a}$ & $62.1 \mathrm{~b}$ & $55.4 \mathrm{~b}$ & $60.4 \mathrm{a}$ & $106.3 \mathrm{~b}$ & $0.64 \mathrm{a}$ \\
\hline Sun4/shade2 & $85.5 \mathrm{~b}$ & $91.0 \mathrm{~b}$ & $103.5 \mathrm{c}$ & $13.5 \mathrm{~b}$ & $15.8 \mathrm{a}$ & $17.7 \mathrm{~b}$ & $60.7 \mathrm{~b}$ & $55.7 \mathrm{c}$ & $57.1 \mathrm{~b}$ & $52.2 \mathrm{a}$ & $127.0 \mathrm{~b}$ & $0.43 \mathrm{~b}$ \\
\hline Sun $2 /$ shade 4 & $82.4 \mathrm{~b}$ & $92.9 \mathrm{~b}$ & $115.7 \mathrm{~b}$ & $12.5 \mathrm{c}$ & $14.4 \mathrm{~b}$ & $17.1 \mathrm{~b}$ & $65.5 \mathrm{a}$ & $64.7 \mathrm{~b}$ & $68.7 \mathrm{a}$ & $48.0 \mathrm{a}$ & $119.3 \mathrm{~b}$ & $0.40 \mathrm{~b}$ \\
\hline Full sun & $83.1 \mathrm{~b}$ & $90.8 \mathrm{c}$ & $95.0 \mathrm{~b}$ & $11.3 \mathrm{a}$ & $13.6 \mathrm{a}$ & $16.7 \mathrm{a}$ & $74.1 \mathrm{ab}$ & $67.0 \mathrm{c}$ & $56.5 \mathrm{~b}$ & $90.6 \mathrm{a}$ & $119.3 \mathrm{a}$ & $0.77 \mathrm{a}$ \\
\hline Sun $4 /$ shade 2 & $83.0 \mathrm{~b}$ & $90.0 \mathrm{c}$ & $97.5 \mathrm{~b}$ & $11.9 \mathrm{a}$ & $14.2 \mathrm{a}$ & $15.9 \mathrm{a}$ & $69.8 \mathrm{~b}$ & $63.9 \mathrm{c}$ & $59.3 \mathrm{~b}$ & $78.1 \mathrm{a}$ & $124.2 \mathrm{a}$ & $0.61 \mathrm{~b}$ \\
\hline Sun $2 /$ shade 4 & $83.5 \mathrm{~b}$ & $99.3 \mathrm{~b}$ & $122.2 \mathrm{a}$ & $11.6 \mathrm{a}$ & $13.8 \mathrm{a}$ & $16.5 \mathrm{a}$ & $72.0 \mathrm{ab}$ & $72.5 \mathrm{~b}$ & $73.1 \mathrm{a}$ & $68.3 \mathrm{a}$ & $131.2 \mathrm{a}$ & $0.49 \mathrm{c}$ \\
\hline Full shade & $92.7 \mathrm{a}$ & $109.8 \mathrm{a}$ & $124.5 \mathrm{a}$ & $12.2 \mathrm{a}$ & $14.1 \mathrm{a}$ & $17.0 \mathrm{a}$ & $76.0 \mathrm{a}$ & $79.4 \mathrm{a}$ & $71.6 \mathrm{a}$ & $91.4 \mathrm{a}$ & $151.5 \mathrm{a}$ & $0.58 \mathrm{bc}$ \\
\hline
\end{tabular}

${ }^{\mathrm{z} F u l l}$ sun exposure throughout the growing season of 6 months (full sun), full sun exposure for 4 months and placement under $53 \%$ black shadecloth for 2 mo. (sun $4 /$ shade 2 ), full sun exposure for 2 months and placement under $53 \%$ black shadecloth for 4 months (sun 2 /shade 4 ), and full shade exposure under $53 \%$ black shadecloth throughout the growing season (full shade).

${ }^{\mathrm{y}} 1 \mathrm{~cm}=0.3937$ inch; $1 \mathrm{~g}=0.0353 \mathrm{oz}$

${ }^{\mathrm{x}} \mathrm{S}$ tem diameter at 6 inches $(15.2 \mathrm{~cm})$ above the substrate; $1 \mathrm{~mm}=0.0394$ inch.

${ }^{\mathrm{w}}$ Means followed by the same letter within a taxon are not significantly different according to the Shaffer-simulated adjustment for multiple comparisons $(\alpha=0.05)$.

Table 2. Powdery mildew disease severity (in October) and progress (AUDPC) of Cherokee Brave ${ }^{\mathrm{TM}}$ and 'Cherokee Princess' flowering dogwood planted as bare-root plants in no. 7 [ $23 \mathrm{~L}(6.1 \mathrm{gal})]$ containers in a pine bark substrate on 12 Mar. 2015 and grown using four different shade treatments in McMinnville, TN.

\begin{tabular}{lccccr}
\hline & \multicolumn{2}{c}{ Cherokee Brave $^{\mathrm{TM}}$} & & \multicolumn{2}{c}{ 'Cherokee Princess' } \\
\cline { 2 - 3 } \cline { 5 - 6 } Treatment $^{\mathrm{z}}$ & Disease severity (\%) $^{\mathrm{y}}$ & AUDPC $^{\mathrm{T}}$ & & Disease severity (\%) & AUDPC \\
\hline Full sun & $15.1 \mathrm{~b}^{\mathrm{x}}$ & $452.4 \mathrm{~b}$ & $7.4 \mathrm{c}$ & $391.2 \mathrm{c}$ \\
Sun4/shade2 & $11.9 \mathrm{~b}$ & $402.8 \mathrm{~b}$ & $16.3 \mathrm{~b}$ & $496.7 \mathrm{~b}$ \\
Sun2/shade4 & $28.5 \mathrm{a}$ & $651.7 \mathrm{a}$ & $31.3 \mathrm{a}$ & $741.3 \mathrm{a}$ \\
Full shade & $27.5 \mathrm{a}$ & $634.2 \mathrm{a}$ & $19.5 \mathrm{~b}$ & $591.5 \mathrm{~b}$
\end{tabular}

${ }^{\mathrm{z} F u l l}$ sun exposure throughout the growing season of 6 months (full sun), full sun exposure for 4 months and placement under $53 \%$ black shadecloth for 2 months (sun 4 /shade 2 ), full sun exposure for 2 months and placement under 53\% black shadecloth for 4 months (sun2/shade4), and full shade exposure under $53 \%$ black shadecloth throughout the growing season (full shade).

${ }^{y}$ Disease severity and area under the disease progress curve (AUDPC) were based on the percentage of foliage affected; AUDPC was calculated according to the following formula: $\Sigma\left\{\left[\left(\mathrm{x}_{\mathrm{i}}+\mathrm{x}_{\mathrm{i}-1}\right) / 2\right]\left(\mathrm{t}_{\mathrm{i}}-\mathrm{t}_{\mathrm{i}-1}\right)\right\}$, where $\mathrm{x}_{\mathrm{i}}$ is the foliar rating at each evaluation time and $\left(t_{i}-t_{i-1}\right)$ is the number of days between evaluations.

${ }^{x}$ Means followed by the same letter within a column are not significantly different according to the Shaffersimulated adjustment for multiple comparisons $(\alpha=0.05)$.

Tennessee to minimize powdery mildew severity and maximize crop growth and quality (Halcomb, 2002).

Most commercial nurseries produce flowering dogwood in full sun and plants are subjected to stress with long-term sun exposure and supraoptimal root zone temperature (RZT). RZT in nursery containers can reach $54{ }^{\circ} \mathrm{C}$ during the summer, but plant growth can cease at RZTs above $38^{\circ} \mathrm{C}$ (Ingram et al., 2015; Markham et al., 2011). RZTs during container production commonly reach over $42^{\circ} \mathrm{C}$ in the southeastern United States, and they can reach over $50{ }^{\circ} \mathrm{C}$ in other parts of the country, including Ohio and Washington (Mathers, 2003). Moderating RZT during production would reduce plant stress and improve crop growth and quality. Nevertheless, methods of reducing RZT must be practical for adoption at commercial nurseries. Growing crops under shadecloth or delaying spacing of containers can reduce RZT by minimizing solar radiation of the container sidewall, which is the main source of heat buildup in nursery containers (Ingram et al., 2015). Montague et al. (1992) reported that flowering dogwood had greater growth (plant height and stem diameter) when grown under black or white shadecloth compared with plants grown in full sun. Additionally, the container substrate temperature was $6^{\circ} \mathrm{F}$ lower under shade compared with full sun. Burrows et al. (2015) also reported greater flowering dogwood growth under different types of shadecloth (black $30 \%$, black $50 \%$, and white $50 \%$ ) compared with full sun, although the differences occurred later in the season (August), suggesting that plants grown in full sun were exposed to longer durations of high temperatures that were detrimental to plant growth. Burrows et al. (2015) also noted that the RZT was greatly reduced under $50 \%$ shadecloth (regardless of color) compared with $30 \%$ shadecloth and full sun. Shade culture could also aggravate the powdery mildew incidence in flowering dogwood. Powdery mildew develops and spreads more readily under high humidity conditions (Baysal-Gurel and Fare, 2016; Baysal-Gurel and Gunter, 2018). Plants under shade culture benefit from the reduced light intensity, but the shadecloth limits air flow, thus contributing to increased humidity and incidence of powdery mildew.

Liner type/size, transplant container size, and finished container size will vary by crop species and grower preference. Nursery growers may choose to transplant liners into the finished container size and hold the plants until the crop reaches a marketable size, whereas others prefer to transplant into an intermediate container size to potentially avoid crop stress and shorten the crop cycle (Beeson, 1991). Flowering dogwood has a moderate growth rate but can vary by cultivar. No published reports 


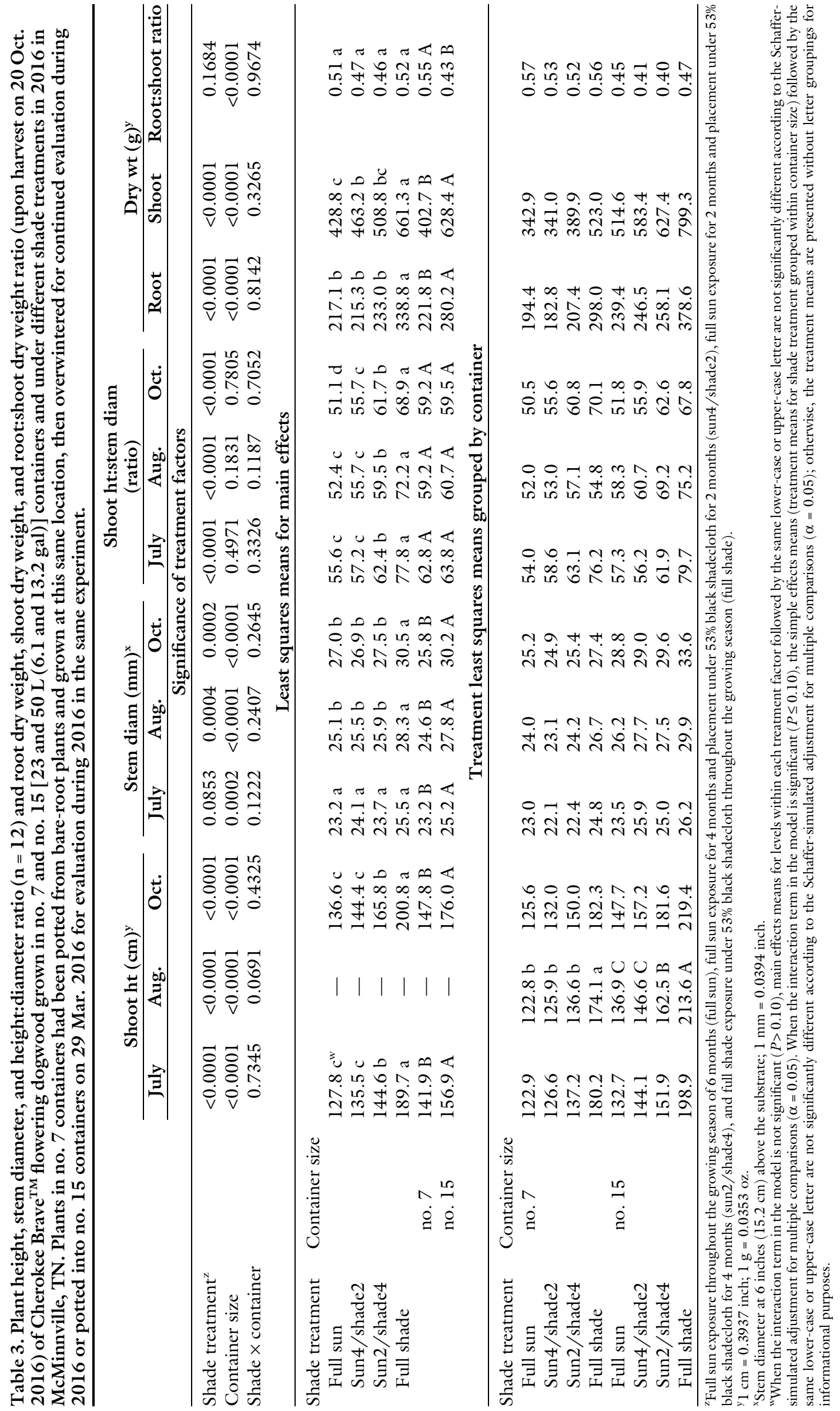




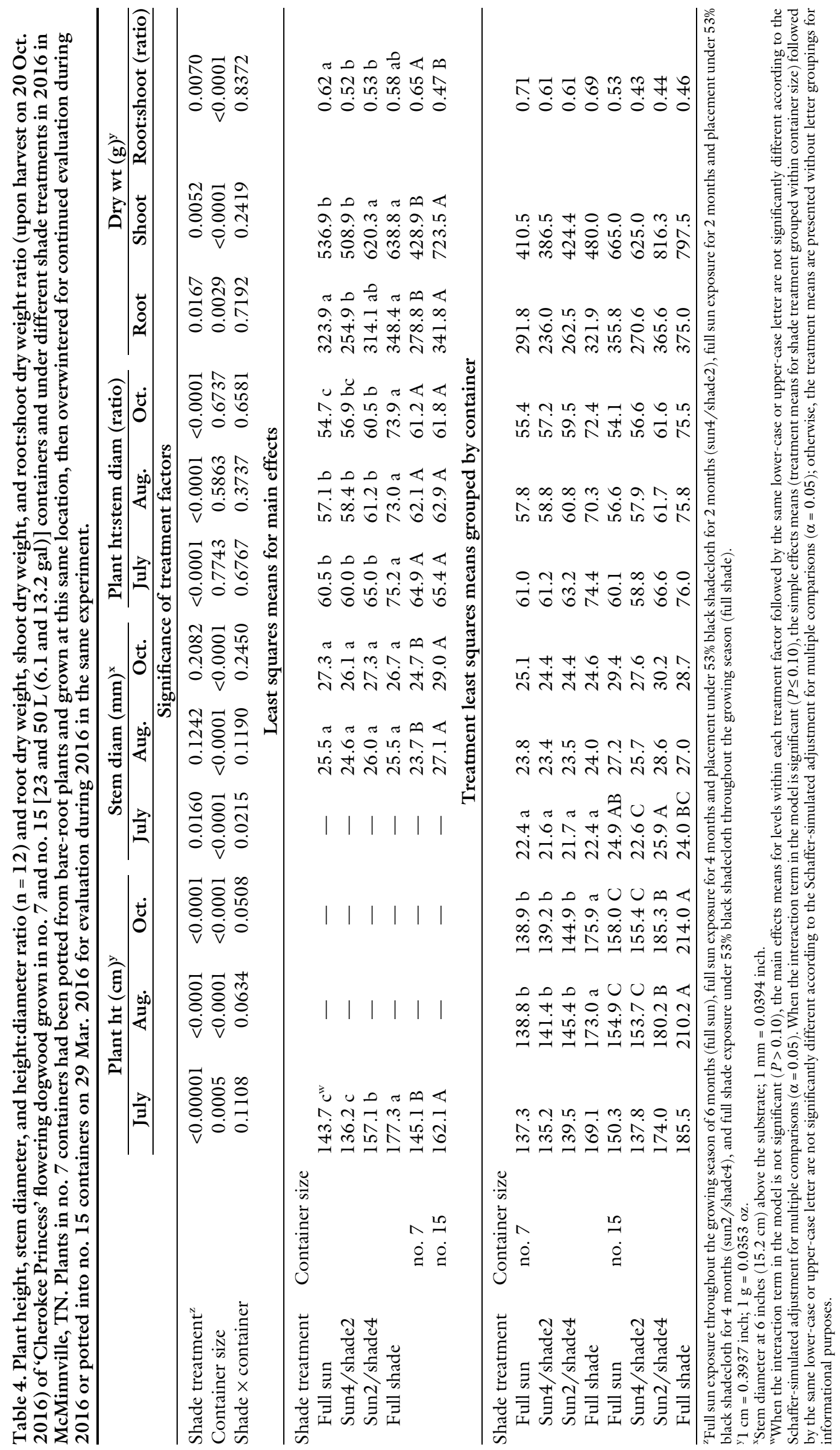


Table 5. Powdery mildew severity (in September) and progress (AUDPC) of Cherokee Brave ${ }^{\mathrm{TM}}$ and 'Cherokee Princess' flowering dogwood grown in no. 7 and no. 15 [23 and $50 \mathrm{~L}(6.1$ and 13.2 gal)] containers and under different shade treatments in 2016 in McMinnville, TN. Plants in no. 7 containers had been potted from bare-root plants and grown at this same location, then overwintered for continued evaluation during 2016 or potted into no. 15 containers on 29 Mar. 2016 for evaluation during 2016 in the same experiment.

\begin{tabular}{|c|c|c|c|c|}
\hline & \multicolumn{2}{|c|}{ Cherokee Brave $^{\mathrm{TM}}$} & \multicolumn{2}{|c|}{ 'Cherokee Princess' } \\
\hline & Disease severity $(\%)^{y}$ & AUDPC $^{y}$ & Disease severity (\%) & AUDPC \\
\hline & \multicolumn{4}{|c|}{ Significance of treatment factors } \\
\hline Container size & 0.0224 & 0.0425 & 0.1552 & 0.0189 \\
\hline Shade $\times$ container & 0.0062 & 0.1602 & 0.0141 & 0.3415 \\
\hline
\end{tabular}

Least squares means for main effects

\begin{tabular}{|c|c|c|c|c|c|}
\hline Shade treatment & Container size & & & & \\
\hline Full sun & & 1.1 & $219.7 \mathrm{~b}$ & 1.8 & $459.8 \mathrm{~b}$ \\
\hline Sun $4 /$ shade 2 & & 3.3 & $291.2 \mathrm{~b}$ & 2.8 & $519.9 \mathrm{~b}$ \\
\hline Sun $2 /$ shade 4 & & 2.4 & $276.4 \mathrm{~b}$ & 4.9 & $731.2 \mathrm{~b}$ \\
\hline Full shade & & 19.8 & $1607.8 \mathrm{a}$ & 10.6 & $1603.1 \mathrm{a}$ \\
\hline & no. 7 & 5.6 & $566.1 \mathrm{~B}$ & 4.5 & $669.4 \mathrm{~B}$ \\
\hline & no. 15 & 7.7 & $631.4 \mathrm{~A}$ & 5.6 & $987.5 \mathrm{~A}$ \\
\hline
\end{tabular}

Treatment least squares means grouped by container

\begin{tabular}{|c|c|c|c|c|c|}
\hline Shade treatment & \multirow{2}{*}{$\begin{array}{l}\text { Container size } \\
\text { no. } 7\end{array}$} & & & & \\
\hline Full sun & & $1.1 \mathrm{~b}^{\mathrm{x}}$ & 225.5 & $1.7 \mathrm{~b}$ & 319.3 \\
\hline Sun $4 /$ shade 2 & & $2.7 \mathrm{~b}$ & 329.3 & $2.8 \mathrm{~b}$ & 488.5 \\
\hline Sun $2 /$ shade 4 & & $1.9 \mathrm{~b}$ & 239.7 & $5.9 \mathrm{ab}$ & 545.2 \\
\hline Full sun & no. 15 & $1.1 \mathrm{~b}$ & 213.9 & $1.9 \mathrm{~b}$ & 600.2 \\
\hline Sun $4 /$ shade 2 & & $3.9 \mathrm{~b}$ & 253.0 & $2.9 \mathrm{~b}$ & 551.4 \\
\hline Sun $2 /$ shade 4 & & $2.9 \mathrm{~b}$ & 313.0 & $4.0 \mathrm{~b}$ & 917.2 \\
\hline $\begin{array}{l}{ }^{\mathrm{z}} \text { Shade treatment: full } \\
\text { months (sun } 4 / \text { shade2 } \\
\text { shadecloth throughou } \\
{ }^{y} \text { Disease severity and a } \\
\sum\left(\left[\left(\mathrm{x}_{\mathrm{i}}+\mathrm{x}_{\mathrm{i}-1}\right) / 2\right]\left(\mathrm{t}_{\mathrm{i}}-\mathrm{t}_{\mathrm{i}-1}\right)\right) \\
{ }^{\mathrm{x}} \text { When the interaction te } \\
\text { are not significantly diffe } \\
\text { effects means (treatmen } \\
\text { Schaffer-simulated adjus }\end{array}$ & $\begin{array}{l}\text { osure throughout the } \\
\text { in exposure for } 2 \text { mon } \\
\text { owing season (full sha } \\
\text { er the disease progres } \\
\mathrm{x}_{\mathrm{i}} \text { is the foliar rating a } \\
\text { e model is not significa } \\
\text { rding to Schaffer-simul } \\
\text { for shade treatment gro } \\
\text { or multiple comparison }\end{array}$ & $\begin{array}{l}\text { of } 6 \text { montl } \\
\text { ent under } 5 \\
\text { PC) were ba } \\
\text { on time and } \\
\text { e main effect }\end{array}$ & $\begin{array}{l}\text { sun exposur } \\
\text { cloth for } 4 \mathrm{~m} \\
\text { ge foliage af } \\
\text { mber of day } \\
\text { within each } \\
=0.05) \text {. When } \\
\text { ame lower-ca } \\
\text { are presentec }\end{array}$ & $\begin{array}{l}\text { placement u } \\
\text { 4), and full s } \\
\text { culated acco } \\
\text { ns. } \\
\text { wed by the sa } \\
\text { in the model } \\
\mathrm{r} \text { are not sign } \\
\text { pings for infe }\end{array}$ & $\begin{array}{l}\text { hadecloth for } 2 \\
\text { inder } 53 \% \text { black } \\
\text { owing formula: } \\
\text { upper-case letter } \\
0.10) \text {, the simple } \\
\text { according to the } \\
\text { ses. }\end{array}$ \\
\hline
\end{tabular}

Schaffer-simulated adjustment for multiple comparisons $(\alpha=0.05)$; otherwise, the treatment means are presented without letter groupings for informational purposes.

have detailed the production schedule for flowering dogwood in large (no. 7 or no. 15 ) containers. Demonstrating effective cultural practices that maximize flowering dogwood growth and quality will assist nursery growers in selecting proper production schedules for container-grown flowering dogwood. The objective of this research was to evaluate growth and powdery mildew severity of two cultivars of flowering dogwood bareroot liners over a 2 -year production cycle in no. 7 and no. 15 containers under varying periods of shade exposure.

\section{Materials and methods}

A 2-year study (2015-16) was conducted at the Otis L. Floyd Nursery Research Center of Tennessee State University in McMinnville, TN (USDA
Plant Hardiness Zone 7a). On 10 Mar. 2015, uniform bare-root flowering dogwood 'Cherokee Princess' and 'Comco No. 1' (Cherokee Brave ${ }^{\mathrm{TM}}$ ) liners (18-24 inches tall) were obtained from a commercial nursery in Winchester, TN. On 12 Mar. 2015, liners (160 per cultivar) were transplanted into no. 7 nursery containers (C2800; Nursery Supplies, Chambersburg, PA) filled with a pine bark substrate (Sims Bark, Tuscumbia, AL) amended with $11 \mathrm{lb} /$ yard $^{3}$ $19 \mathrm{~N}-2.2 \mathrm{P}-7.5 \mathrm{~K}$ controlled-release fertilizer [ 147 g per no. 7 container (19-59 Osmocote Pro 12 to 14-month; Everris, Dublin, OH)], 1.5 lb/yard ${ }^{3}$ micronutrient granules (Micromax; Everris), and $1 \mathrm{lb} /$ yard $^{3}$ media surfactant granules (AquaGro; Aquatrols, Paulsboro, NJ). Plants were irrigated via overhead sprinklers until 4 May, at which time plants were moved to gravel- covered growing beds (containers spaced $2 \mathrm{ft}$ apart) and assigned to one of four shade treatments: full sun exposure throughout the growing season of 6 months (full sun); full sun exposure for 4 months, then placed under shade for 2 months (sun $4 /$ shade 2 ); full sun exposure for 2 months, then placed under shade for 4 months (sun2/ shade4); and full shade exposure throughout the growing season (full shade). Plants were placed in a shade structure (containers spaced $2 \mathrm{ft}$ apart) with the top and three sides covered with black woven shadecloth (53\% shade; Cherokee Manufacturing, South St. Paul, MN). Plants were cyclic-irrigated (daily at 5:00 AM, 6:00 AM, and 8:00 AM) using fan emitters [one emitter per container $\left(160^{\circ}\right.$ Spot-Spitter; Primerus Products, Encinita, CA)]. The experiment used a completely 


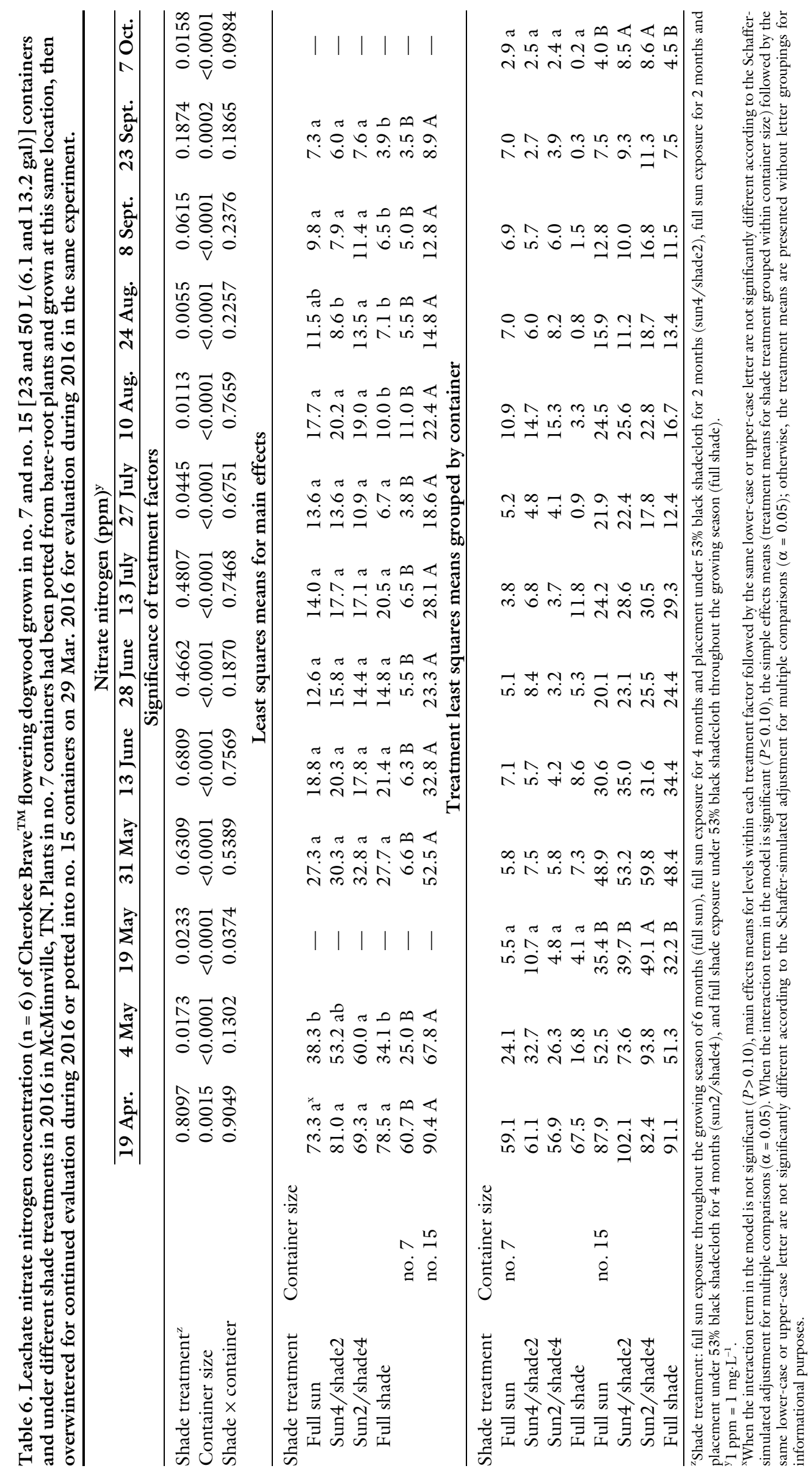




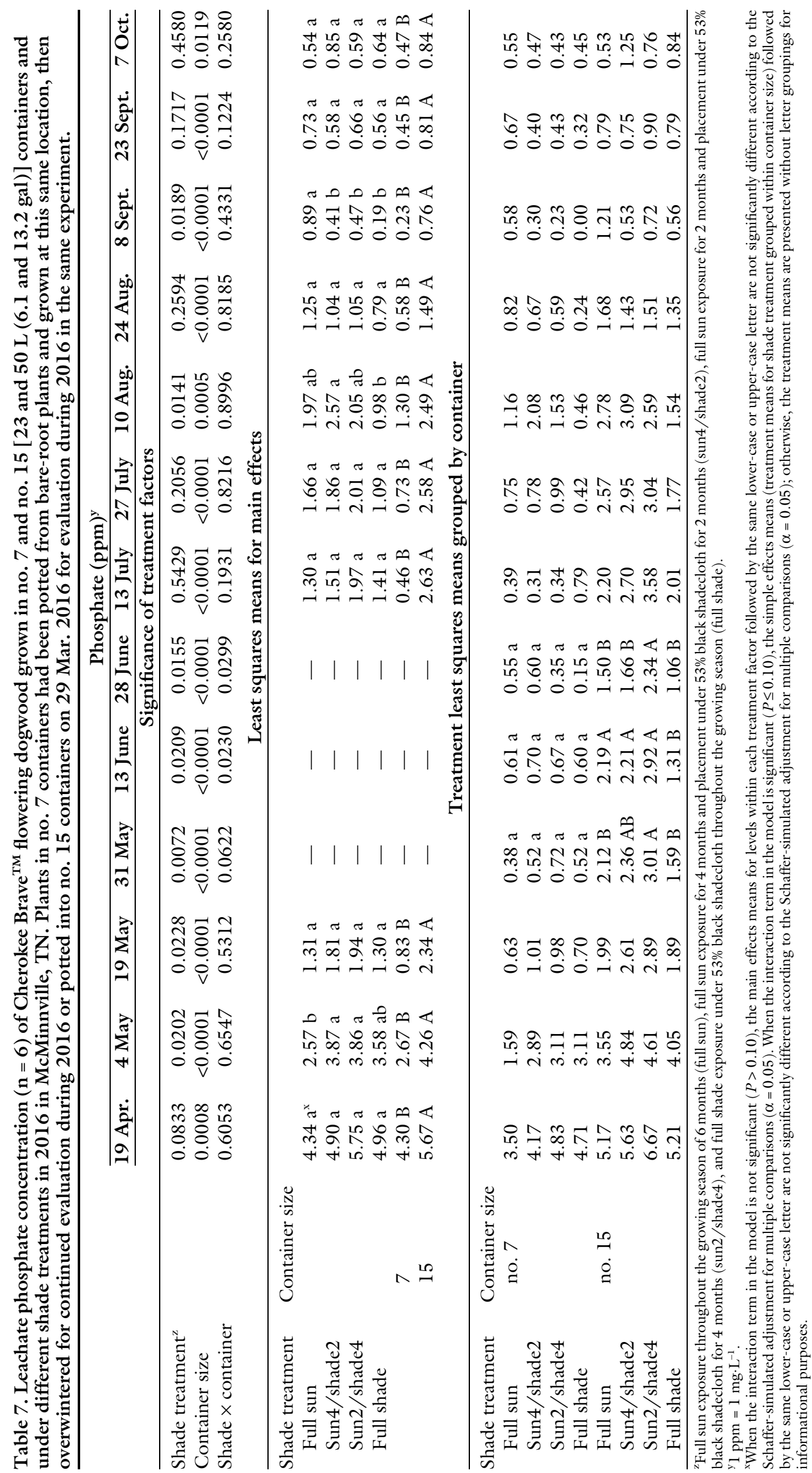




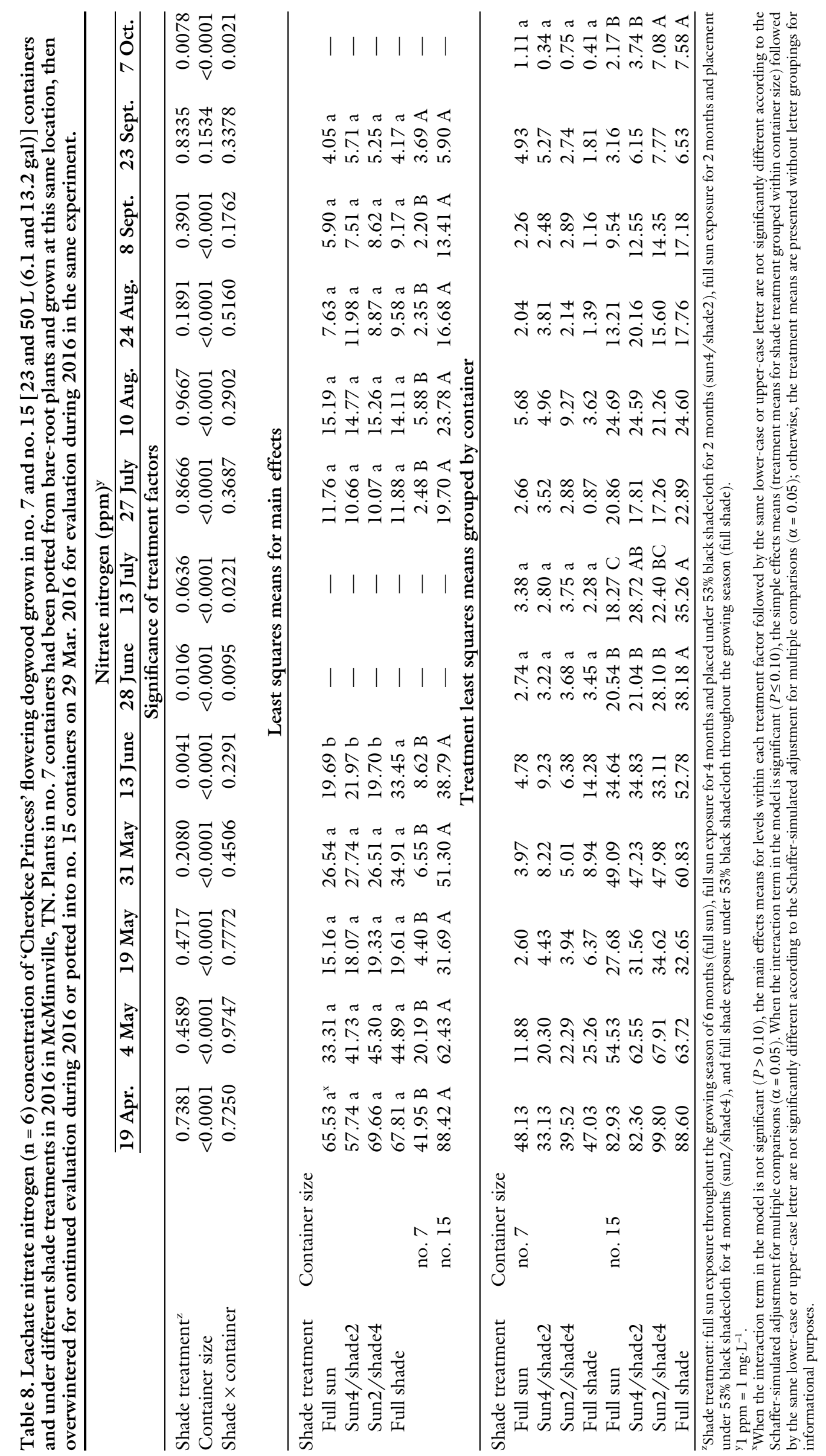




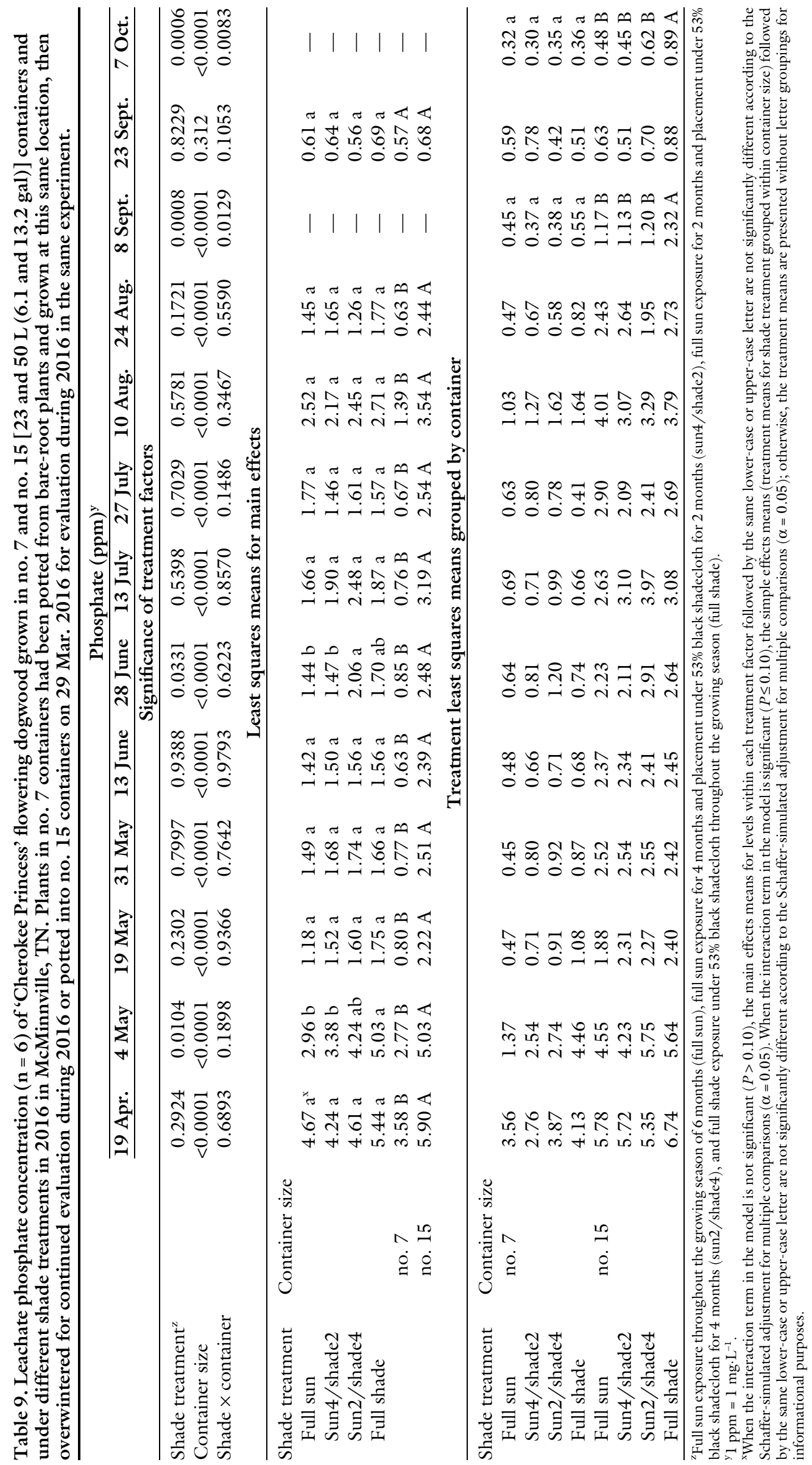


randomized design with 40 plants per replication (40 plants per treatment per cultivar).

On 13 July, 11 Aug., and 3 Nov. 2015 , plant height (centimeters) and stem diameter [millimeters (measured 6 inches above the substrate surface; measurement was taken at the same position on each tree at each collection date)] were recorded for all plants, and the ratio of plant height to stem diameter (HT:Diam) was also calculated. On 15 July, 2 Sept., and 5 Oct. 2015, plants were visually rated for powdery mildew disease severity using a scale of $0 \%$ to $100 \%$ (increments of 10) foliage affected. Values for the area under the disease progress curve (AUDPC) were calculated according to the following formula: $\Sigma\left\{\left[\left(\mathrm{x}_{\mathrm{i}}+\mathrm{x}_{\mathrm{i}-1}\right) / 2\right]\left(\mathrm{t}_{\mathrm{i}}-\mathrm{t}_{\mathrm{i}-1}\right)\right\}$, where $\mathrm{x}_{\mathrm{i}}$ is the foliar rating at each evaluation time and $\left(t_{i}-t_{i-1}\right)$ is the number of days between evaluations. On 5 Nov. 2015, 12 plants from each treatment were randomly selected and harvested. Plants were harvested for shoot and root dry weights (grams) by severing shoots from the roots at the substrate surface, and the ratio of RDW to SDW (RDW:SDW) was also calculated. Pine bark substrate was gently blown from the root mass using a compressed air system at 125 psi. Both roots and shoots were dried in a forced-air oven at $56^{\circ} \mathrm{C}$ for $10 \mathrm{~d}$. The remaining plants were jammed pot-to-pot for overwintering and overhead-irrigated every 2 weeks when $<0.5$ inches of rainfall occurred during the prior 2 -week period.

On 29 Mar. 2016, 12 plants from each shade treatment (48 plants total) were transplanted to no. 15 grip-lip nursery containers (GL6900; Nursery Supplies) filled with a pine bark substrate amended with $11 \mathrm{lb} /$ yard $^{3}$ of $19 \mathrm{~N}-2.2 \mathrm{P}-7.5 \mathrm{~K}$ controlled-release fertilizer ( 330 g per no. 15 container), $1.5 \mathrm{lb} / \mathrm{yard}^{3}$ of micronutrient granules, and $0.5 \mathrm{lb} /$ yard $^{3}$ of media surfactant granules. The remaining 12 plants (from each treatment) were kept in no. 7 nursery containers for the duration of the study, and each no. 7 container was topdressed with $147 \mathrm{~g}$ of $19 \mathrm{~N}-2.2 \mathrm{P}-7.5 \mathrm{~K}$ controlled-release fertilizer. Plants were placed and arranged on a gravel-covered area as previously described and irrigated (as previously described) using one fan emitter (no. 7 nursery containers) or one spray jet emitter [no. 15 nursery containers (Max-14-360; Maxijet, Dundee, FL)] per container. The experiment used a completely randomized design with 12 plants per treatment per cultivar (96 plants per cultivar).

On 14 July, 16 Aug., and 5 Oct. 2016, plant height (centimeters) and stem diameter [millimeters (measured 6 inches above substrate surface)] were recorded for all plants and HT:Diam was calculated. On 18 July, 29 Aug., and 21 Sept. 2016, plants were visually rated for powdery mildew as described. On 20 Oct. 2016, the study was ended and plants were harvested as described. Substrate leachate was collected biweekly in 2016 (13 sampling dates from 19 Apr. to 7 Oct.) using the pourthrough method (Wright, 1986). Pour-through volumes of $250 \mathrm{~mL}$ (no. 7 containers) and $400 \mathrm{~mL}$ (no. 15 containers) were used. Substrate leachate $\mathrm{pH}$ and electrical conductivity (EC) were measured using a multimeter (Agri-meter; Myron L Co., Carlsbad, CA). Leachate nitrate nitrogen $\left(\mathrm{NO}_{3}-\mathrm{N}\right)$ and phosphate $\left(\mathrm{PO}_{4}-\mathrm{P}\right)$ content were analyzed by ion chromatography (Dionex DX600 X Ion Chromatographic System; Thermo Fisher Scientific, Waltham, MA). Ambient (two sensors each in full sun and full shade) and substrate temperatures (two sensors for each container size in sun and shade; sensors were inserted in the southwest side of the container 3 inches from the sidewall to a depth of 2 inches) were recorded (Watchdog 425 Logger; Spectrum Technologies, Aurora, IL) in September, and data were summarized using temperatures (recorded every $30 \mathrm{~min}$ ) from 12:00 $\mathrm{PM}$ to 7:00 PM (data not shown).

Weed control was maintained with flumioxazin granular herbicide $[0.375$ lb/acre a.i. (BroadStar; Valent U.S.A. Corp., Walnut Creek, CA)] throughout the study. To control broad mites (Polyphagotarsonemus latus), the insecticides bifenthrin $[0.003 \mathrm{lb} / 1000$ $\mathrm{ft}^{2}$ a.i. (Talstar P Professional; FMC Corp, Philadelphia, PA)], pyridaben $[0.2 \mathrm{lb} / 100 \mathrm{gal}$ a.i. (Sanmite; Gowan Co., Yuma, AZ)], spiromesifen $[0.1 \mathrm{lb} / 100$ gal a.i. (Judo; OHP, Mainland, PA)], and clarified hydrophobic extract of neem oil $[5.5 \mathrm{lb} /$ 100 gal a.i. (Triact 70; Certis USA, Columbia, MD)] were used in rotation and applied using an airblast sprayer throughout the study. A routine fungicide spray schedule was used for the prevention and control of powdery mildew. The fungicide mefenoxam $\left[0.06 \mathrm{lb} / 1000 \mathrm{ft}^{2}\right.$ a.i. (Subdue GR; Syngenta Crop Protection, Greensboro, NC)] was applied as a soil surface application. The fungicides thiofanate-methyl $[0.5$ lb/100 gal a.i. (Cleary's 3336F; Cleary Chemicals, Alsip, IL)] and propiconazole $[0.03 \mathrm{lb} / 100 \mathrm{gal}$ a.i. (Banner MAXX II, Syngenta Crop Protection)] were applied using an airblast sprayer throughout the study.

The single-factor data from 2015 (shade treatments) were analyzed with linear mixed models using the GLIMMIX procedure of SAS (version 9.4; SAS Institute, Cary, NC). The two-factor data from 2016 (shade treatments and container size) were analyzed using linear mixed models using the GLIMMIX procedure of SAS by first testing for an interaction between treatment factors (container size and shade duration). Levels of main effects were compared when there was no interaction between treatment factors. When there was an interaction between the treatment factors, levels of shade duration were compared within each container size. $P$ values for all simultaneous comparisons were adjusted using the Shaffersimulated method to maintain an overall significance level of $\alpha=0.05$.

\section{Results and discussion}

2015 Experiment. Cherokee Brave $^{\mathrm{TM}}$ plants grown in full shade were taller compared with all other treatments when measured in July, August, and November (Table 1). Shade duration also affected the rate of increased growth in Cherokee Brave $^{\mathrm{TM}}$, where height increased $17 \%$ (full sun) to $37 \%$ (full shade) from July to November. 'Cherokee Princess' plant height followed a trend similar to Cherokee Brave ${ }^{\mathrm{TM}}$, yet overall differences in height (among treatments) were less pronounced. 'Cherokee Princess' plants with full shade were taller compared with all other plants in July and August, but height was similar for plants with full shade and sun 2 /shade 4 in November. Stem diameter of Cherokee Brave $^{\mathrm{TM}}$ was greatest with full shade throughout 2015. No differences in stem diameter occurred among treatments for 'Cherokee Princess'. For both cultivars, HT:Diam were similar 
with full sun and full shade in July, but it was significantly greater with full shade in August and November.

Overall, plant growth (height and stem diameter) was comparable between cultivars at the end of 2015 . Final mean heights were 94.2 and $95.0 \mathrm{~cm}$ (Cherokee Brave ${ }^{\mathrm{TM}}$ and 'Cherokee Princess', respectively) with full sun; however, with full shade, final mean heights were 135.6 and 124.5 $\mathrm{cm}$ (Cherokee Brave' $\mathrm{T}^{\mathrm{TM}}$ and 'Cherokee Princess', respectively). Final stem diameters were also similar for both cultivars, averaging $16.8 \mathrm{~cm}$ (Cherokee Princess) to $18.2 \mathrm{~cm}$ $\left(\right.$ Cherokee Brave $\left.{ }^{\mathrm{TM}}\right)$.

For both cultivars, RDW was similar among all treatments but SDW was greater with full shade than with all other treatments for Cherokee Brave $^{\mathrm{TM}}$ while no differences occurred for SDW of 'Cherokee Princess'. Nevertheless, SDW was $63 \%$ (Cherokee Brave $^{\mathrm{TM}}$ ) and $27 \%$ greater with full shade than with full sun. The RDW:SDW for Cherokee Brave ${ }^{\mathrm{TM}}$ was similar among all plants grown with any duration of shade, whereas RDW:SDW for 'Cherokee Princess' with full shade was similar to that with sun $2 /$ shade 4 and sun $4 /$ shade 2 treatments.

Powdery mildew appeared naturally and disease pressure was low to moderate in 2015 , primarily due to fungicide applications. The effects of shade duration on powdery mildew severity (final rating and AUDPC) were significant for both Cherokee Brave $^{\mathrm{TM}}$ and 'Cherokee Princess' (Table 2). Disease severity and AUDPC in Cherokee Brave ${ }^{\mathrm{TM}}$ were greater with sun $2 /$ shade 4 and full shade than with sun $4 /$ shade2 and full sun. 'Cherokee Princess' exhibited greater powdery mildew severity and disease progress with sun $2 /$ shade 4 than with other treatments.

2016 EXPERIMENT. In Mar. 2016, one-half of the plants (for each cultivar) were transplanted into no. 15 nursery containers, and the others remained in no. 7 containers. All plants were subjected to the previously assigned shade treatments. Overall, both cultivars produced in no. 15 containers were larger than those in no. 7 containers and plants were larger in full shade treatment than with full sun treatment. Plant height of both cultivars was greater in no. 15 containers in July after only 3 months of growth (Tables 3 and 4). At the end of the study (Oct. 2016), Cherokee Brave ${ }^{\mathrm{TM}}$ plant height was $19 \%$ greater in no. 15 containers than in no. 7 containers and height was greatest in full shade than with all other treatments. There was an interaction for final height (Oct. 2016) for 'Cherokee Princess': height was greater in sun $2 /$ shade 4 than with full sun in no. 7 containers but not in no. 15 containers. Nevertheless, plants in full shade were taller than all other treatments in no. 7 and no. 15 containers. The larger container also had a positive effect on stem diameter in both cultivars, but full shade only had a positive impact on stem diameter for Cherokee Brave ${ }^{\mathrm{TM}}$.

Plants of both cultivars in no. 15 containers had greater RDW and SDW than plants in no. 7 containers. Full shade also produced the greatest RDW and SDW compared with all other treatments. Plants in no. 15 containers produced 26\% (Cherokee Brave $^{\mathrm{TM}}$ ) and 23\% ('Cherokee Princess') more RDW, whereas SDW was $54 \%$ (Cherokee Brave ${ }^{\mathrm{TM}}$ ) and 19\% ('Cherokee Princess') greater in full shade than with full sun. The RDW:SDW for both cultivars was lower in no. 15 containers.

Powdery mildew appeared naturally and disease pressure was low again in 2016, likely due to the schedule of preventative fungicides that were applied. Powdery mildew severity was greater for plants grown under full shade than with all other treatments in both cultivars (Table 5). In no. 7 containers, powdery mildew severity was at least $14 \%$ greater in full shade than with the other treatments and it was more than $19 \%$ greater in full shade for plants in no. 15 containers. Flowering dogwood (both cultivars) grown in no. 15 containers had greater powdery mildew AUDPC compared with no. 7 containers.

Substrate leachate was analyzed biweekly for $\mathrm{pH}, \mathrm{EC}, \mathrm{NO}_{3}-\mathrm{N}$, and $\mathrm{PO}_{4}-\mathrm{P}$ throughout 2016. Leachate $\mathrm{pH}$ ranged from 4.0 to 7.4 (Cherokee Brave $^{\mathrm{TM}}$ ) and from 4.3 to 6.9 ('Cherokee Princess') during the growing season (data not shown). Overall, leachate $\mathrm{pH}$ was lower and EC was greater for plants in no. 15 containers compared with plants in no. 7 containers, and shade duration had no effect on leachate $\mathrm{pH}$ or EC (data not shown). In general, leachate nutrient concentration $\left(\mathrm{NO}_{3}-\mathrm{N}\right.$ and $\left.\mathrm{PO}_{4}-\mathrm{P}\right)$ was greater for plants in no. 15 containers and shade duration had little effect on nutrient concentration (Tables 6-9). Leachate $\mathrm{NO}_{3}-\mathrm{N}$ concentration was greater in no. 15 containers throughout the experiment for both cultivars, with the exception of one date for Cherokee Princess. When interactions occurred between treatment factors, $\mathrm{NO}_{3}-\mathrm{N}$ concentration was greater for plants in all no. 15 containers compared with plants in all no. 7 containers. The larger container also resulted in greater $\mathrm{PO}_{4}-\mathrm{P}$ concentrations, except on one date for 'Cherokee Princess'. On a few collection dates, an interaction occurred between treatment factors, but the nutrient concentration (regardless of the nutrient) was substantially greater with all treatments involving shade and using no. 15 containers compared with the corresponding treatments using no. 7 containers.

We have demonstrated that bareroot liners can be used to produce marketable no. 15 container-grown flowering dogwood within 2 years. During the first few months of production, transplant shock was mitigated for plants that received shade throughout the growing season (full shade) because they were taller than all other plants by July. Although some plants received shade later in the season, growth was superior in full shade. Shade can provide a number of benefits for the crop, including reduced sun intensity and lower RZT. In our study, average daytime RZT was $5{ }^{\circ} \mathrm{F}$ lower in containers (no. 7 and no. 15) under shade compared with containers in full sun and ambient temperature was $8{ }^{\circ} \mathrm{F}$ lower under shade. Montague et al. (1992) reported similar differences in RZT between containers in full sun $\left(87^{\circ} \mathrm{F}\right)$ and under shade $\left(81^{\circ} \mathrm{F}\right)$. Roots are less tolerant to extreme changes in temperature and can be damaged at temperatures higher than $100^{\circ} \mathrm{F}$, even if exposed for only a few hours per day, resulting in reduced growth (Ingram et al., 2015). Providing shade throughout the first year of production resulted in larger plants overall and would ultimately shorten the period required to produce a finished crop.

During the second year of production, plants in no. 7 containers grew substantially but plants grown in 
no. 15 containers achieved greater growth. The smaller container size could have presented certain limiting factors that prevented growth achieved in no. 15 containers. First, shoot growth can be limited by container size due to restricted root development; therefore, the larger containers had greater root biomass to support increased shoot growth (NeSmith and Duval, 1998). Second, controlled-release fertilizer (CRF) was applied as a topdressing in no. 7 containers but it was incorporated into the substrate in the no. 15 containers during the second year of production. Plants likely benefitted from incorporated CRF which can release nutrients more readily due to high substrate moisture within the container, whereas topdressed CRF must leach into the root zone for absorption (Million et al., 2007). In addition, no. 15 containers received two times more fertilizer than no. 7 container due to the larger volume. As a result, leachate nutrient content was substantially higher in the no. 15 containers, and more nutrients were available for absorption by plant roots and could have contributed to greater plant growth.

Flowering dogwood produced in large containers can be a valuable crop for nursery growers willing to adopt certain beneficial cultural practices. Growers should consider producing flowering dogwood under shade for at least the first growing season to reduce transplant stress and maximize growth. If adequate shaded production space is available or can be constructed, then higherquality plants in no. 15 containers can be produced in two growing seasons. However, vigorous growth due to both container size and shade duration increases the severity of powdery mildew; therefore, routine fungicide applications will be essential for disease management. Further research can examine optimum CRF rates to reduce nutrient leaching while maintaining crop growth. Additionally, fungicide product rotations with different application intervals can be investigated to maximize control of powdery mildew in flowering dogwood.

\section{Literature cited}

Baysal-Gurel, F. and D.C. Fare. 2016. Response of container-grown flowering dogwood cultivars to powdery mildew under sun/shade production and different fertilizer regimes. Proc. Southern Nursery Assn. Res. Conf. 61:141-147.

Baysal-Gurel, F. and J. Gunter. 2018. Powdery mildew on dogwood. Tennessee State Univ. Ext. Publ. ANR-PATH-112018.

Beeson, R.C., Jr. 1991. Scheduling woody plants for production and harvest. HortTechnology 1:30-36.

Burrows, M.W., D.C. Fare, C.H. Gilliam, and D.J. Eakes. 2015. Influence of shading on container-grown flowering dogwoods. Proc. Southern Nursery Assn. Res. Conf. 60:11-18.

Fulcher, A.F. and S.A. White (eds.). 2012. IPM for select deciduous trees in southeastern US nursery production. Southern Nursery IPM Working Group, Knoxville, TN.

Halcomb, M. 2002. Dogwood production: Cornus florida and cultivars. 15 Jan. 2019. <https://extension.tennessee.
edu/mtnpi/Documents/handouts / Production \% 20Guides/ProduceDogwoods.pdf $>$.

Ingram, D.L., J.M. Ruter, and C.A. Martin. 2015. Review: Characterization and impact of supraoptimal root-zone temperatures in container-grown plants. HortScience 50:530-539.

Markham, J.W., D.J. Bremer, C.R. Boyer, and K.R. Schroeder. 2011. Effect of container color on substrate temperatures and growth of red maple and redbud. HortScience 46:721-726.

Mathers, H.M. 2003. Summary of temperature stress issues in nursery containers and current methods of protection. HortTechnology 13:617-624.

Million, J., T. Yeager, and J. Albano. 2007. Effects of container spacing practice and fertilizer placement on runoff from overhead-irrigated sweet viburnum. J. Environ. Hort. 25:61-72.

Montague, D.T., D.J. Eakes, C.H. Gilliam, K.M. Tilt, and H.G. Ponder. 1992. Shade during container production of flowering dogwood increases growth. Proc. Southern Nursery Assn. Res. Conf. 37:19-21.

NeSmith, D.S. and J.R. Duval. 1998. The effect of container size. Hort Technology 8:495-498.

U.S. Department of Agriculture. 2019. 2012 Census of agriculture. 4 Mar. 2019. $<$ https://quickstats.nass.usda.gov/>.

Witte, W.T., M.T. Windham, A.S. Windham, F.A. Hale, D.C. Fare, and W.K. Clatterbuck. 2000. Dogwoods for American gardens. Univ. Tennessee Coop. Ext. Publ. PB1670.

Wright, R.D. 1986. The pour-through nutrient extraction procedure. HortScience 21:227-229. 